\title{
Protein secondary structures ( $\alpha$-helix and $\beta$-sheet) at a cellular level and protein fractions in relation to rumen degradation behaviours of protein: a new approach
}

\author{
Peiqiang $\mathrm{Yu}^{*}$ \\ Department of Animal and Poultry Science, University of Saskatchewan, 51 Campus Drive, Saskatoon, SK, Canada, S7N 5A8 \\ (Received 22 March 2005 - Revised 25 May 2005 - Accepted 26 May 2005)
}

\begin{abstract}
Studying the secondary structure of proteins leads to an understanding of the components that make up a whole protein, and such an understanding of the structure of the whole protein is often vital to understanding its digestive behaviour and nutritive value in animals. The main protein secondary structures are the $\alpha$-helix and $\beta$-sheet. The percentage of these two structures in protein secondary structures influences protein nutritive value, quality and digestive behaviour. A high percentage of $\beta$-sheet structure may partly cause a low access to gastrointestinal digestive enzymes, which results in a low protein value. The objectives of the present study were to use advanced synchrotron-based Fourier transform IR (S-FTIR) microspectroscopy as a new approach to reveal the molecular chemistry of the protein secondary structures of feed tissues affected by heat-processing within intact tissue at a cellular level, and to quantify protein secondary structures using multicomponent peak modelling Gaussian and Lorentzian methods, in relation to protein digestive behaviours and nutritive value in the rumen, which was determined using the Cornell Net Carbohydrate Protein System. The synchrotron-based molecular chemistry research experiment was performed at the National Synchrotron Light Source at Brookhaven National Laboratory, US Department of Energy. The results showed that, with S-FTIR microspectroscopy, the molecular chemistry, ultrastructural chemical make-up and nutritive characteristics could be revealed at a high ultraspatial resolution $(\sim 10 \mu \mathrm{m})$. S-FTIR microspectroscopy revealed that the secondary structure of protein differed between raw and roasted golden flaxseeds in terms of the percentages and ratio of $\alpha$-helixes and $\beta$-sheets in the mid-IR range at the cellular level. By using multicomponent peak modelling, the results show that the roasting reduced $(P<0.05)$ the percentage of $\alpha$-helixes (from $47.1 \%$ to $36.1 \%$ : S-FTIR absorption intensity), increased the percentage of $\beta$-sheets (from $37.2 \%$ to $49.8 \%$ : S-FTIR absorption intensity) and reduced the $\alpha$-helix to $\beta$-sheet ratio (from 0.3 to 0.7 ) in the golden flaxseeds, which indicated a negative effect of the roasting on protein values, utilisation and bioavailability. These results were proved by the Cornell Net Carbohydrate Protein System in situ animal trial, which also revealed that roasting increased the amount of protein bound to lignin, and well as of the Maillard reaction protein (both of which are poorly used by ruminants), and increased the level of indigestible and undegradable protein in ruminants. The present results demonstrate the potential of highly spatially resolved synchrotron-based infrared microspectroscopy to locate 'pure' protein in feed tissues, and reveal protein secondary structures and digestive behaviour, making a significant step forward in and an important contribution to protein nutritional research. Further study is needed to determine the sensitivities of protein secondary structures to various heat-processing conditions, and to quantify the relationship between protein secondary structures and the nutrient availability and digestive behaviour of various protein sources. Information from the present study arising from the synchrotron-based IR probing of the protein secondary structures of protein sources at the cellular level will be valuable as a guide to maintaining protein quality and predicting digestive behaviours.
\end{abstract}

Synchrotron-based FTIR microspectroscopy: Feed molecular chemistry: Protein secondary structures: $\alpha$-Helix: $\beta$-Sheet: Protein nutritive value: Digestive behaviour: Protein fractions

Studying the secondary structure of proteins leads to an understanding of the components that make up a whole protein (Dyson \& Wright, 1990; Carey, 1996), and such as understanding of the structure of the whole protein is often vital to understanding its digestive behaviour, nutritive quality, utilisation and availability in animals. Protein secondary structures include mainly the $\alpha$-helix and $\beta$-sheet, with small numbers of $\beta$-turns and random coils (Carey, 1996; Fig. 1). The percentage of these structures influences protein quality, nutrient utilisation, availability and digestive behaviour (Yu, 2004; Yu et al. 2004c). A high percentage of the $\beta$-sheet structure may partly cause a low access to gastrointestinal digestive enzymes, which results in a low protein value and low protein availability. However, studies on protein secondary structures in relation to the nutritive value and digestive behaviour of protein in animals are extremely rare. Our recent primary research showed that different protein sources had different percentages and ratios of $\alpha$-helixes and $\beta$-sheets in their protein secondary structures (Yu et al. 2004c). These protein structures were highly associated with protein nutritive value.

In ruminants, heat-processing has been used to improve the utilisation and availability of nutrients ( $\mathrm{Yu}$ et al. 2002) and inactivate anti-nutritional factors (van der Poel et al. 1990), for example by reducing the solubility of the protein, fermentation and metabolism in the rumen, increasing the amount of protein entering the small intestine for absorption and digestion ( $\mathrm{Yu}$ et al. 2002), reducing the hydrogenation of conjugated linoleic

Abbreviations: CP, crude protein; CNCPS, Cornell Net Carbohydrate and Protein System; FSD, Fourier self-convolution; NDF, neutral detergent fibre; NRC, National Research Council; S-FTIR, synchrotron-based Fourier transform IR.

* Corresponding author: Dr Peiqiang Yu, fax 306966 4151, email yupe@ sask.usask.ca 
(a)
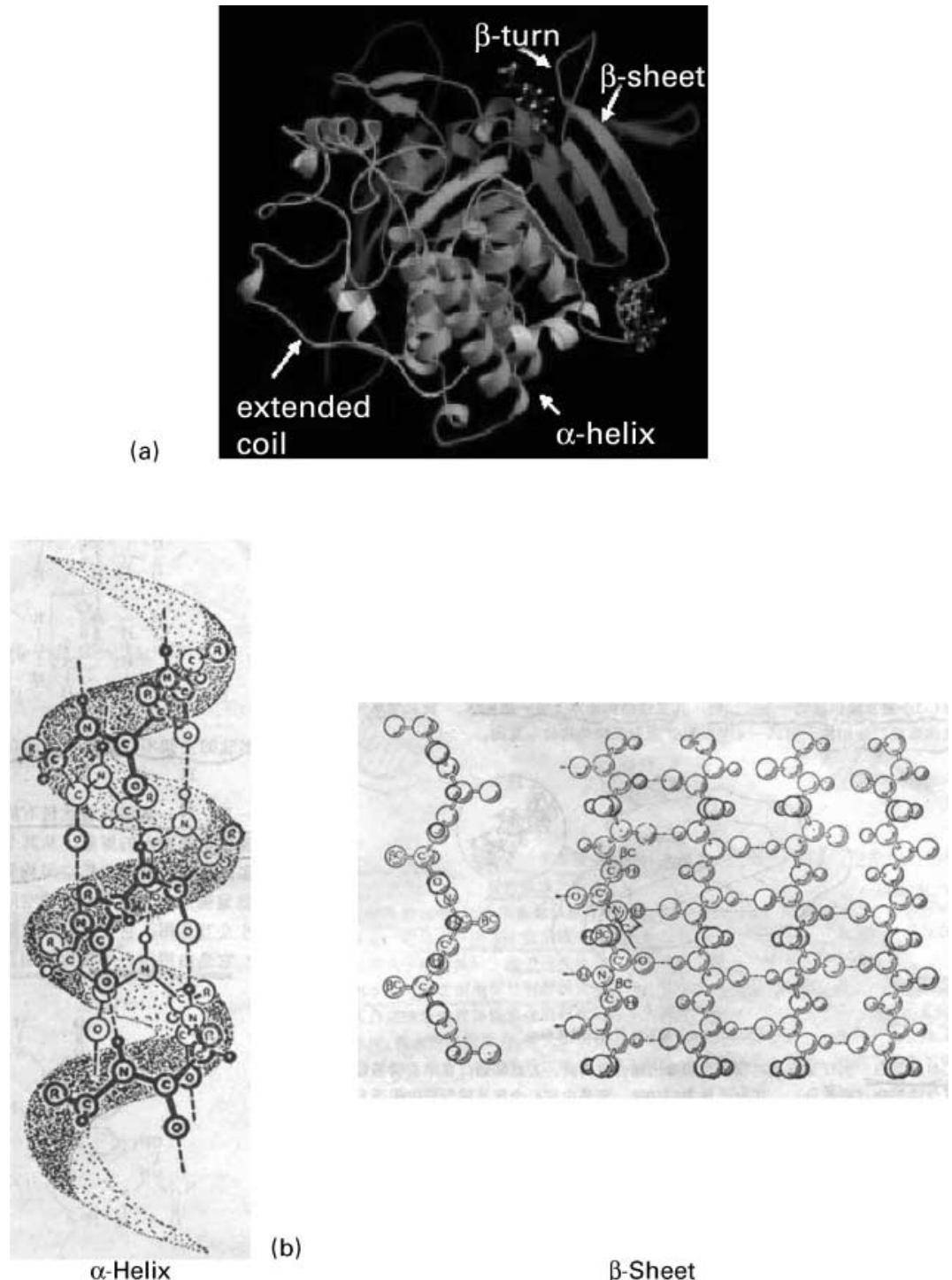

(b)

$\beta$-Sheet

Fig. 1. (A) Schematics of protein secondary structure (including the $\alpha$-helix and $\beta$-sheet) (eg Dumas, 2003). (B) Protein secondary structure of the $\alpha$-helix and $\beta$ sheet.

acid in the rumen and increasing the amount of conjugated linoleic acid available in the small intestine (Soita et al. 2003). The basic mechanism of altering protein digestive behaviour (Goelema, 1999) with heat-processing involves the denaturation, unfolding or uncoiling of a coiled or pleated structure (Holum, 1982). Any temperature change in the environment of the protein that can influence the non-covalent interactions involved in the structure may lead to an alteration of protein structure (Goelema, 1999), including protein secondary structure. New research (Seguchi et al. 2004) showed that heat-processing affected protein secondary structures and changed the $\alpha$-helix to $\beta$-sheet ratio of egg white protein. These changes affected nutritive quality.

A published review shows that the effects of heat-processing on protein nutritive value, utilisation, availability and performance in animals are highly equivocal (Yu et al. 2004g). Part of the reason is that the heating conditions inside a feed may not be optimal, the feed being either underheated or overheated ( $\mathrm{Yu}$ et al. 2004g). One of the methods often used for assessing protein digestive behaviour in ruminants is the Cornell Net Carbohydrate Protein System (CNCPS; Sniffen et al. 1992; Chalupa \& Sniffen,
1994), which partitions the protein into five fractions in relation to degradation behaviour in the rumen. One new approach proposed here to check the effects of heat-processing on protein value and nutrient availability is to look at the magnitude of changes in the protein secondary structures in the intrinsic protein structures of relatively 'pure' protein tissues, in terms of the percentages of $\alpha$-helixes and $\beta$-sheets, as well as the $\alpha$-helix to $\beta$ sheet ratio, within the intact tissue. Most studies have focused on total chemical composition affected by heat-processing using traditional 'wet' chemical analysis without any consideration of inherent structural and matrix effects (Yu, 2004). As we know, the protein value, quality, utilisation, availability and digestive behaviour are closely related not only to total chemical composition, but also to inherent structures and the component matrix (Yu et al. 2003a, 2004a,d; Yu, 2004).

Traditional 'wet' chemical analysis fails to reveal feed structure and structural matrix information (Yu, 2004), and fails to link tissue structural to chemical information (Budevska, 2002). Advanced synchrotron-based Fourier transform IR (S-FTIR) microspectroscopy has recently been developed as a rapid, 
direct, non-invasive, non-destructive bioanalytical technique (Wetzel et al. 1998; Holman et al. 2002; Miller, 2002; Marinkovic et al. 2002; Yu, 2005a), mostly for medical research. The technique takes advantage of synchrotron light brightness (being 100-1000 million times brighter than sunlight), and the small effective source size is capable of exploring the molecular chemistry within the structure of biological tissues without destroying structures inherent at a cellular level (Wetzel et al. 1998; Wetzel, 2001; Marinkovic et al. 2002; Miller, 2000, 2002; Yu, 2004). With S-FTIR, 'pure' protein and protein structural characteristics can be localised, and protein structural features can be revealed at a cellular level (Wetzel et al. 2003; Yu et al. 2004c).

There has to date been very little application of this new technique to the study of inherent feed structures in relation to nutrient utilisation, digestive behaviour and availability in animals (Yu, 2004). No research has been carried out to study the ultrastructural chemical and nutritive features of protein secondary structures in a feed within intact 'pure' protein tissue at a cellular level in relation to feed protein quality, utilisation and availability in animals.

The objectives of the present study were to use the advanced synchrotron technology (S-FTIR) as a new approach to reveal the molecular chemistry of the protein secondary structures of feed tissues affected by heat-processing within intact tissue at a cellular level, and to quantify protein secondary structures using multicomponent peak modelling Gaussian and Lorentzian methods, in relation to protein digestive behaviours and nutritive value in the rumen, which was determined using CNCPS. Information from the present study gained from the IR probing of feed protein secondary structures will be valuable as a guide to maintaining protein quality. It is believed that using the advanced synchrotron technology (S-FTIR) will provide an important contribution to protein nutritional research.

\section{Materials and methods}

\section{Feed samples and heat-processing}

The sample feed used for the present study was flaxseed. Raw (ID\# 194-F1) and roasted golden (ID\# 196-F2, 325 ${ }^{\circ}$ F) flaxseeds were obtained from CanMar Grain Products Ltd (Regina, SK, Canada) through Dr David A. Christensen's Research Laboratory (University of Saskatchewan, Canada).

\section{Partitioning protein fractions}

The crude protein $(\mathrm{CP})$ fractions were partitioned according to the CNCPS (Sniffen et al. 1992; Chalupa \& Sniffen, 1994). Characterisation of the CP fractions as applied by this system is as follows: fraction PA is non-protein $\mathrm{N}$ (the fraction of $\mathrm{CP}$ that is instantaneously solubilised at time zero), fraction $\mathrm{PB}$ is true protein, and fraction PC is unavailable protein. Fraction PB is further divided into three fractions that are believed to have different rates of degradation in the rumen (Sniffen et al. 1992):

- PB1 - the fraction of CP that is soluble in borate-phosphate buffer and precipitated with TCA;

- PB2 - total CP minus the sum of fractions PA, PB1, PB3 and $\mathrm{PC}$;

- PB3 - the difference between the portions of total CP recovered with neutral detergent fibre and acid detergent fibre.
Buffer-insoluble protein minus fraction $\mathrm{PB} 3$ is used to estimate fraction PB2. Fraction PB2 is insoluble in buffer but soluble in neutral detergent, whereas fraction PB3 is insoluble in both buffer and neutral detergent, but is soluble in acid detergent. Fraction PB2 is fermented in the rumen at a lower rate than the buffersoluble fractions, and some of the PB2 fraction escapes to the lower gut. Fraction PB3 is believed to be more slowly degraded in the rumen than fractions PB1 and PB2 because of its association with the plant cell wall; a large proportion of $\mathrm{PB} 3$ is thus believed to escape the rumen. Fraction PC is acid detergent-insoluble $\mathrm{N}$, which is highly resistant to breakdown by microbial and mammalian enzymes, and is assumed to be unavailable to the animal (Sniffen et al. 1992).

The relative rumen degradation rates of the five protein fractions have been described by Sniffen et al. (1992) as follows: fraction PA is rapidly degradable with a degradation rate assumed to be infinity; fraction PB1 is rapidly degradable with a degradation rate of $120-400 \% / \mathrm{h}$; fraction PB2 is intermediately degradable, possessing a degradation rate of $3-16 \% / \mathrm{h}$; fraction PB3 is slowly degradable with a degradation rate of 0.06$0.55 \% / \mathrm{h}$; fraction $\mathrm{PC}$ is unavailable and considered to be undegradable.

\section{Energy values}

Estimated energy contents for total digestible nutrients at $1 \times$ maintenance, digestible energy at a production level of intake, metabolisable energy at a production level of intake and net energy for lactation at a production level of intake were estimated from the National Research Council (NRC) dairy model (National Research Council, 2001), whereas metabolisable energy, net energy for maintenance and net energy for growth were estimated from the NRC beef model (National Research Council, 1996).

\section{Chemical analysis}

Laboratory samples of the flaxseeds were prepared by grinding them to pass through a $1 \mathrm{~mm}$ screen. The DM (Association of Official Analytical Chemists official method 930.15), ash (official method 942.05), ether extract (official method 954.02) and CP (official method 984.13) contents were analysed according to the Association of Official Analytical Chemists (1990) procedure. The acid detergent fibre, neutral detergent fibre (NDF) and acid detergent lignin values were analysed according to the procedures of Van Soest et al. (1991). NDF was determined without sodium sulphite (Van Soest et al. 1991). The acid detergent-insoluble N and neutral detergent-insoluble $\mathrm{N}$ values were determined according to the procedures of Licitra et al. (1996). Non-protein N content was obtained from the precipitation of true protein in the filtrate with TCA (final concentration $10 \%$ ) and determined as the difference between total $\mathrm{N}$ and the $\mathrm{N}$ content of the residue after filtration. Total soluble $\mathrm{CP}$ was determined by incubating the sample with $\mathrm{HCO}_{3}-\mathrm{PO}_{4}$ buffer and filtering through Whatman filter paper. The true protein was calculated according to formulae of the NRC dairy model (National Research Council, 2001). All chemical analyses were carried out in duplicate. If, however, the error of chemical analysis was more than $2 \%$, we reanalysed the chemical composition. The average values for analysed chemical composition are presented. 


\section{S-FTIR slide preparation}

Flaxseed samples were cut into thin $(6 \mu \mathrm{m}$ thick) cross-sections at the Western College of Veterinary Medicine, University of Saskatchewan, Canada. The unstained cross-sections were mounted onto Low-e IR microscope slides (Kevley Technologies, Chesterland, OH, USA) for S-FTIR microspectroscopy in reflectance mode. A more detailed methodology for slide preparation and analysis has been reported by Yu et al. (2003b, 2004e,f, 2005a).

\section{Synchrotron light source and FTIR microspectroscopy}

The experiment (completely random design) was performed at the National Synchrotron Light Source at Brookhaven National Laboratory (Department of Energy, New York, USA). The beamline U10B (NSLS) was equipped with an FTIR spectrometer (Nicolet Magna 860) with $\mathrm{KBr}$ beam-splitter and liquid N-cooled mercury cadmium telluride (MCT) detectors (Nicolet Magna 860, Thermo Nicolet, USA) coupled with a Continum IR microscope (Spectra Tech, USA) with a Schwartzshild $32 \times$ objective and $10 \times$ condenser. Synchrotron radiation from the Vacuum Ultra Violet storage ring at beamline U10B (with an energy level of $800 \mathrm{MeV}$ ) entered the interferometer via an instrument port designed for IR emission. The IR spectra were collected in the mid-IR range of $4000-800 \mathrm{~cm}^{-1}$ at a resolution of $4 \mathrm{~cm}^{-1}$ with sixty-four scans co-added. The aperture setting was $10 \times 10 \mu \mathrm{m}$. Stage control, spectrum data collection and processing were performed using an OMNIC 6.0 (Spectra Tech). Scanned visible images were obtained using a charge-coupled device camera (Nicolet Magna 860) linked to the IR images.

\section{Data analysis and chemical images}

The spectral data of the flaxseed tissues were collected, corrected with the background spectrum, displayed in the absorbance mode and analysed using the OMNIC 6.0 (Spectra Tech). The data were displayed either as a series of spectroscopic images collected at individual wavelengths or as a collection of IR spectra obtained at each pixel position in the image. The S-FTIR absorbance was expressed as $\log (1 / \mathrm{R})$. Chemical functional groups were identified according to published reports (Kemp, 1991; Himmelsbach et al. 1998; Wetzel et al. 1998; Jackson \& Mantsch, 2000; Wetzel, 2001; Marinkovic et al. 2002; Miller, 2002). Chemical imaging of the protein (amide I) and the protein to starch ratio in the intrinsic structures of the flaxseed tissues were determined by the OMNIC $6 \cdot 0$ software at the spectral region $\left(1650-1550 \mathrm{~cm}^{-1}, 1025 \mathrm{~cm}^{-1}\right)$ of greatest interest. The protein to starch peak ratio was obtained from the height under the amide I functional group band $\left(1650 \mathrm{~cm}^{-1}\right)$ divided by the height under the starch functional group band $\left(1025 \mathrm{~cm}^{-1}\right)$ for each scan area (scan size $10 \times 10 \mu \mathrm{m}$ ) (Wetzel et al. 1998; Yu et al. 2003b; Yu, 2005b).

The chemical mapping of the protein and protein to starch ratio at the beamline U10B provided spectral data selected with relatively 'pure' protein for modelling protein amide I component peaks. The selection procedure of the 'pure' protein in the flaxseed tissues followed the methodology published by Wetzel et al. (2003). The brief procedure is described below.

Within each image of the raw and roasted golden flaxseed tissues, ten area samples in the endosperm region with the relatively pure 'protein' content were selected for quantification of protein secondary structures ( $\alpha$-helix to $\beta$-sheet ratio) at ultraresolution following the procedure of Wetzel et al. (2003). This is because the endosperm matrix is heterogeneous. In order to eliminate the carbohydrate-scattering effect on the protein spectrum, the relatively 'pure' protein areas were selected for protein secondary structure analysis. The size of each probed area was $10 \times 10 \mu \mathrm{m}$, which was within plant cellular dimensions $(5-30 \mu \mathrm{m})$.

\section{Percentage of $\alpha$-helixes and $\beta$-sheets in feed protein secondary} structures

Because the protein amide I component bands overlapped (Fig. 2), a specific multipeak fitting or modelling procedure was required. To determine the relative amounts of $\alpha$-helixes and $\beta$-sheets in the protein secondary structures, two steps were applied. The first step was using Fourier self-deconvolution (FSD) to obtain the FSD spectrum in the protein amide I region in order to identify the protein amide I component peak frequencies (Fig. 2). The detailed concepts and algorithm of FSD (a method for resolving intrinsically overlapped bands) have been described in Kauppinen et al. (1981) and Griffiths \& Pariente (1986). The second step was using a multipeak fitting program with Gaussian and Lorentzian functions (Fig. 3) using Origin data analysis software (Origin Lab Corporation Northampton, MA, USA) to quantify the multicomponent peak areas in the protein amide I bands (Fig. 4). The differences between Gaussian and Lorentzian functions for multicomponent peak fitting and sample curves are shown in Fig. 3. The detailed descriptions were reported in Origin in terms of the peak shape, centre, offset, width and area. The relative amounts of $\alpha$-helixes and $\beta$-sheets based on the modelled peak areas were calculated according to the report generated by the software (Fig. 4).

\section{Statistical analysis}

Statistical analyses for this completely random design experimental design were performed using SAS (SAS, 1998) with the model:

$$
\begin{aligned}
\mathrm{Y}= & \text { mean }+ \text { treatments }+ \text { fitting methods }+ \text { treatments } \\
& \times \text { fitting method }+ \text { error }
\end{aligned}
$$

where treatments $=\mathrm{F} 1$ and $\mathrm{F} 2$, and multipeak fitting methods $=$ Gaussian and Lorentzian functions. Significance was taken as $P<0.05$.

\section{Results and discussion}

\section{Chemical composition of the raw and roasted golden flaxseed}

Table 1 presents the averages of the chemical analysis data for each composition of each flaxseed treatment. The percentage of analysis error was according to the laboratory analysis standard. The raw golden flaxseed had a similar chemical composition, in terms of ash and CP, to roasted flaxseed (Table 1). The raw flaxseed was, however, lower in acid detergent fibre, NDF, acid detergent lignin $(18 v .72 \mathrm{~g} / \mathrm{kg} \mathrm{NDF})$, non-protein $\mathrm{N}(145 v .248 \mathrm{~g} / \mathrm{kg}$ $\mathrm{DM}$ ), acid detergent-insoluble $\mathrm{CP}$ and neutral detergent-insoluble CP (133 v. $196 \mathrm{~g} / \mathrm{kg} \mathrm{CP}$ ), and higher in soluble CP (761 v. $209 \mathrm{~g} /$ $\mathrm{kg} \mathrm{CP}$ ) than the roasted flaxseed. These results indicate that the roasting increased the fibre, lignin and neutral detergent-insoluble $\mathrm{CP}$ content. The higher soluble CP content of the raw flaxseed compared with the roasted flaxseed indicated that the roasting reduced protein solubility. 
(A)

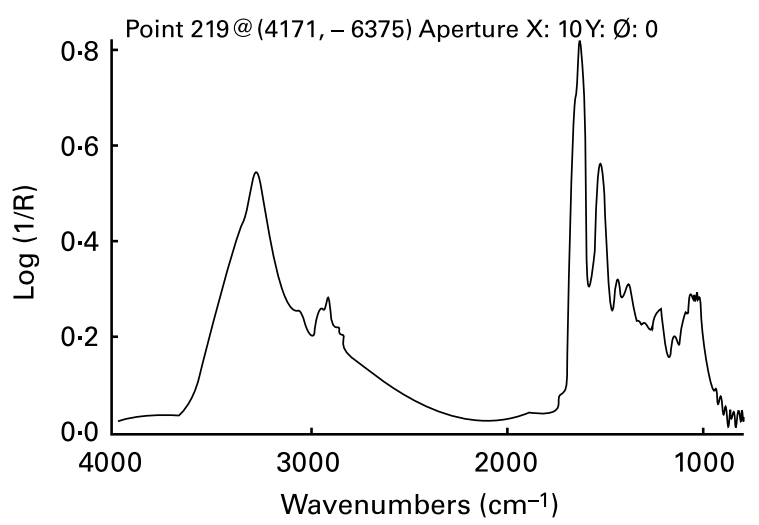

(C)

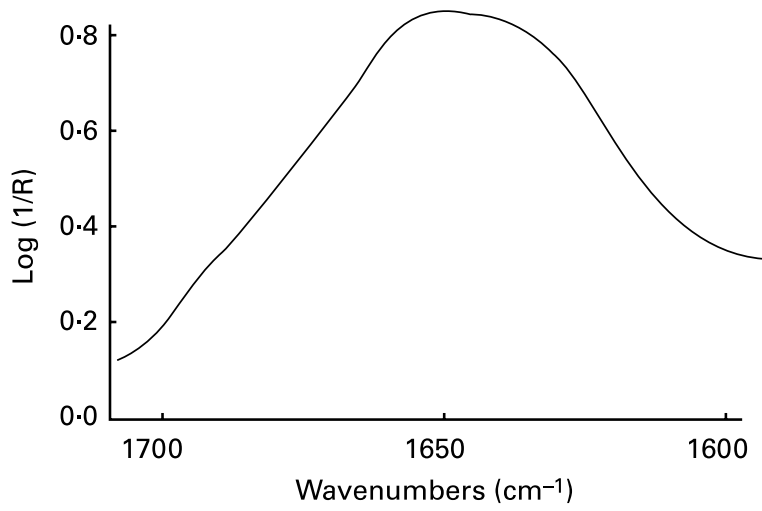

(B)

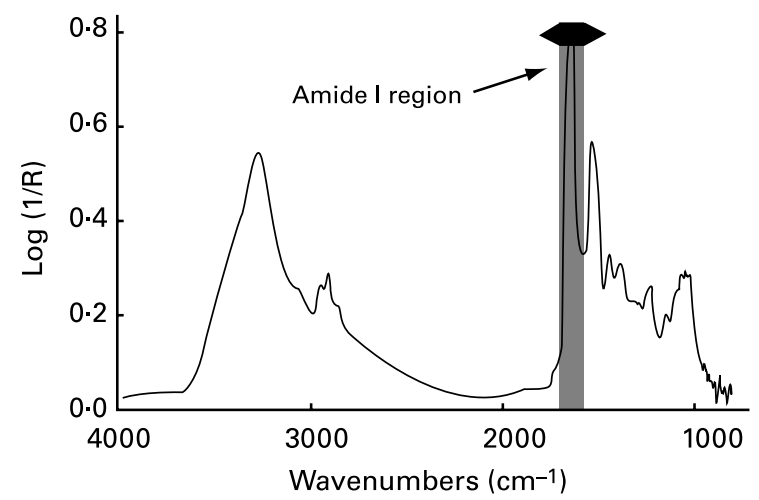

(D)

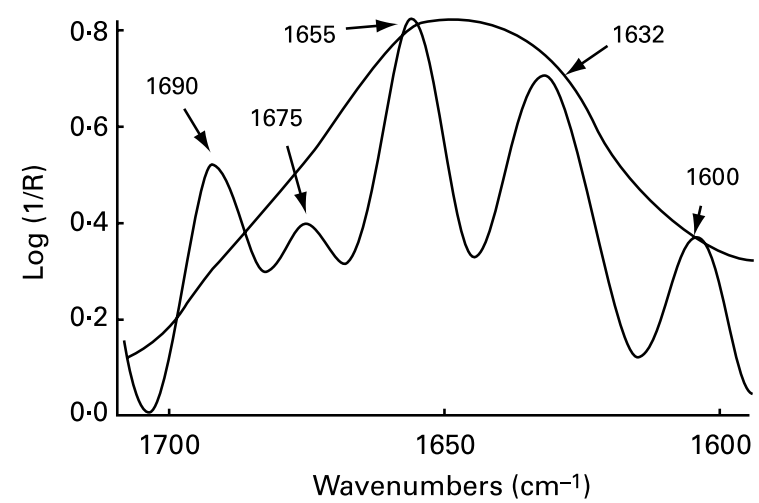

Fig. 2. Typical synchrotron-based Fourier transform IR microspectroscopy spectrum and Fourier self-deconvolution (FSD) spectrum of flaxseed. (A) Full-range spectrum. (B) Amide I region. (C) Protein amide I band. (D) FSD spectrum of amide I.

\begin{tabular}{|c|c|c|c|}
\hline $\begin{array}{l}\text { Multi-peak } \\
\text { fitting } \\
\text { methods }\end{array}$ & Equation and description & Sample curve & \\
\hline $\begin{array}{l}1 . \\
\text { Gaussian } \\
\text { function }\end{array}$ & $\begin{array}{l}y=y_{0}+\frac{A}{w \sqrt{\pi / 2}} e^{-2 \frac{\left(x-x_{c}\right)^{2}}{w^{2}}} \\
{\left[y=y_{0}+\left(\mathrm{A} /\left(\mathrm{w}^{*} \operatorname{sqrt}(\mathrm{P} / / 2)\right)\right)^{*} \exp \left(-2^{*}\left(\left(\mathrm{x}-\mathrm{x}_{c}\right) / \mathrm{w}\right)^{\wedge} 2\right)\right]}\end{array}$ & $\mathrm{w}_{1}$ & $\begin{array}{l}\frac{A>0}{\text { offset: }} y_{0}=1 \\
\text { centre: } x_{c}=2 \\
\text { width: } w=1.5 \\
\text { area: } A=5\end{array}$ \\
\hline & $\begin{array}{l}\text { Where, } y_{0}, x_{c}, w \text { and } A \text { represent offset, centre, } \\
\text { width and area, respectively. }\end{array}$ & $\mathrm{y}=\mathrm{y}_{0}$ & $\begin{array}{l}+\mathrm{A} /\left(\mathrm{w}^{*} \operatorname{sqrt}(\mathrm{pi} / 2)\right) \\
/ \operatorname{sqr}(\ln (4))\end{array}$ \\
\hline $\begin{array}{l}2 . \\
\text { Lorentzian } \\
\text { function }\end{array}$ & $\begin{array}{l}y=y_{0}+\frac{2 A}{\pi} \frac{w}{4\left(x-x_{c}\right)^{2}+w^{2}} \\
{\left[y=y_{0}+\left(2^{*} \mathrm{~A} / \mathrm{PI}\right)^{*}\left(\mathrm{w} /\left(4^{*}\left(\mathrm{x}-\mathrm{x}_{\mathrm{c}}\right)^{\wedge} 2+\mathrm{w}^{\wedge} 2\right)\right)\right]} \\
\text { Where, } \mathrm{y}_{0}, \mathrm{x}_{\mathrm{c}}, \mathrm{w} \text { and A represent offset, centre, } \\
\text { width and area, respectively. }\end{array}$ & $\begin{array}{l}\frac{A, w>0}{\text { offset: }} y_{0}=0 \\
\text { centre: } x_{c}=5 \\
\text { width: } w=2 \\
\text { area: } A=1\end{array}$ & \\
\hline
\end{tabular}

Fig. 3. Gaussian and Lorentzian functions using multipeak fitting in the protein amide I regions.

Energy content of the raw and roasted golden flaxseeds

A summative approach was used to derive the total digestible nutrients at $1 \mathrm{X}$ maintenance value (National Research Council, 2001). In this approach, the concentrations of truly digestible non-fibre carbohydrate, $\mathrm{CP}$, crude fat and NDF for each feed are estimated from Weiss's equations (Weiss et al. 1992). Using these equations, the predicted energy values were similar in the raw and roasted golden flaxseeds (Table 1), with average values for total digestible nutrients at $1 \times$ maintenance of $128 \%$, for digestible energy at a production level of intake, metabolisable energy at a production level of intake and net 



Fig. 4. Multicomponent peaks (approximately 1690, 1675, 1655, 1632 and $1600 \mathrm{~cm}^{-1}$ ) modelling of the typical Fourier self-deconvolution (FSD) spectrum of amide I in flaxseed. Multicomponent modelling took place as follows: step 1 - using FSD in OMNIC to obtain the FSD amide I spectrum; step 2 - using the multipeak fitting program with Gaussian or Lorentzian functions in Origin to quantify the multicomponent peak area in the protein amide I region. (A, C) Typical FSD spectrum of amide I. (B) Multipeak fitting using the Gaussian method, showing $28.1 \% \alpha$-helix, 33.6\% $\beta$-sheet and a $\beta$-sheet to $\alpha$-helix ratio of 1.20 . (D) Multipeak fitting using the Lorentzian method, showing $28.0 \% \alpha$-helix, 33.4\% $\beta$-sheet and a $\beta$-sheet to $\alpha$-helix ratio of 1.21 .

energy for lactation at a production level of intake, using the NRC (2001) dairy model, of $22.7,21.9$ and $15.8 \mathrm{MJ} / \mathrm{kg} \mathrm{DM}$, respectively, and for metabolisable energy, net energy for maintenance and net energy for growth, from the NRC (1996) beef model, of $20.3,14.6$ and $10 \cdot 6 \mathrm{MJ} / \mathrm{kg} \mathrm{DM}$, respectively. The energy value (total digestible nutrients at $1 \mathrm{X}$ maintenance) for flaxseeds is similar to that of rapeseeds, which is $127 \%$, and a little higher than that of oil seeds, which averages $122 \%$ in the NRC (2001) data, suggesting that flaxseed is an attractive alternative to rapeseed as a potential supplement in dairy and beef cattle diets. It has, however, been noted that the energy value of a feed can be determined by different approaches, and the energy values of a feed derived from different methods may not be in agreement with each other (Yu et al. 2004b). Previous work has shown that the use of three approaches (the NRC chemical approach, and in vitro and in situ biological approaches) has resulted in significant differences in the prediction of energy values, the highest predicted values being found using the in situ method, intermediate values coming from the in vitro approach, and the lowest values being seen with the NRC formula method (National Research Council, 2001), indicating that a refinement of the model is needed to predict energy values accurately.

\section{Protein fractions of raw and roasted golden flaxseeds and association with rumen degradation characteristics}

In models designed to assess the utilisation of feed protein by ruminants, it is assumed that most of the soluble protein (PA and PB1) is completely and quickly degraded in the rumen, and that varying proportions of the insoluble fractions (PB2, PB3, PC) escape ruminal degradation depending on the interactive effects of digestion and passage (Sniffen et al. 1992). Because various protein fractions differ in their rate and extent of ruminal degradation, the proportions of these different protein fractions in feedstuffs are believed to influence the amounts of ruminally degraded and escaping protein consumed by animals (Elizalde et al. 1999). Table 1 illustrates the quantitative effect of roasting the flaxseeds on the components and proportions of the protein (PA, PB1, PB2, PB3, PC) fractions. Comparing the raw and the roasted seeds, the raw seeds were higher in PA (43v. $21 \mathrm{~g} / \mathrm{kg} \mathrm{DM})$ and PB1 (255v. $64 \mathrm{~g} / \mathrm{kg} \mathrm{DM})$, but lower in PB2 (41 v. $243 \mathrm{~g} / \mathrm{kg} \mathrm{DM}), \mathrm{PB} 3$ (41 v. $243 \mathrm{~g} / \mathrm{kg} \mathrm{DM})$ and $\mathrm{PC}(12 v .16 \mathrm{~g} / \mathrm{kg} \mathrm{DM})$, indicating large and potential differences in rumen $\mathrm{CP}$ degradation characteristics between the raw and the roasted golden flaxseeds. The higher PA and PB1 content of the raw flaxseeds indicated that the roasting process reduced the level of soluble protein (PA + PB1), which is quickly degraded in the rumen. The presence of smaller PB2 and PB3 fractions associated with the cell wall in the raw flaxseeds indicated that roasting increased the proportions degraded at low and intermediate speeds. Fraction PC consists of protein bound to lignin and Maillard reaction protein. From the nutritional point of view, this fraction appears to be essentially indigestible, and the amount apparently digested is poorly used by the ruminant animal (Sniffen et al. 1992; Chaudhry \& Webster, 1993; Rebolé et al. 2001). In the present study, the roasted flaxseed had a higher PC fraction than the 
Table 1. Chemical composition, crude protein (CP) fractions following the Cornell Net Carbohydrate and Protein System (CNCPS) and energy values of the raw and roasted golden flaxseed

(Values and standard deviations)

\begin{tabular}{|c|c|c|c|c|}
\hline \multirow[b]{3}{*}{ Item } & \multicolumn{4}{|c|}{ Golden flaxseed } \\
\hline & \multicolumn{2}{|c|}{ Raw } & \multicolumn{2}{|c|}{ Roasted } \\
\hline & Value & SD & Value & SD \\
\hline \multicolumn{5}{|l|}{ Chemical composition } \\
\hline $\mathrm{DM}(\mathrm{g} / \mathrm{kg})$ & $904 \cdot 0$ & 0.4 & $941 \cdot 0$ & 0.03 \\
\hline Ash (g/kg DM) & 61.9 & $2 \cdot 0$ & 63.5 & 0.5 \\
\hline Crude fat (g/kg DM) & $429 \cdot 6$ & $2 \cdot 3$ & $461 \cdot 0$ & $3 \cdot 1$ \\
\hline $\mathrm{CP}(\mathrm{g} / \mathrm{kg} \mathrm{DM})$ & $392 \cdot 0$ & 3.7 & $408 \cdot 8$ & $6 \cdot 1$ \\
\hline Acid detergent fibre (g/kg DM) & $127 \cdot 0$ & $2 \cdot 4$ & $135 \cdot 1$ & 0.2 \\
\hline Neutral detergent fibre (g/kg DM) & $362 \cdot 1$ & $7 \cdot 2$ & $381 \cdot 2$ & $9 \cdot 8$ \\
\hline Acid detergent lignin ( $\mathrm{g} / \mathrm{kg}$ neutral detergent fibre) & 1.79 & 0.4 & $7 \cdot 19$ & 0.3 \\
\hline Soluble CP $(\mathrm{g} / \mathrm{kg} \mathrm{CP})$ & $761 \cdot 3$ & $6 \cdot 1$ & $208 \cdot 5$ & 1.5 \\
\hline Non-protein N (g/kg SCP) & $145 \cdot 3$ & $5 \cdot 1$ & 248.5 & $7 \cdot 7$ \\
\hline Neutral detergent-insoluble CP ( $/ \mathrm{kg} \mathrm{CP})$ & $133 \cdot 3$ & $1 \cdot 2$ & $196 \cdot 2$ & $2 \cdot 9$ \\
\hline Acid detergent-insoluble CP ( $\mathrm{g} / \mathrm{kg} \mathrm{CP})$ & $31 \cdot 4$ & $1 \cdot 3$ & $38 \cdot 3$ & 1.6 \\
\hline \multicolumn{5}{|l|}{ Protein fractions following the CNCPS system ${ }^{*}$} \\
\hline$P A(g / k g ~ C P)$ & & $110 \cdot 6$ & & $51 \cdot 8$ \\
\hline PB1 (g/kg CP) & & $650 \cdot 7$ & & $156 \cdot 7$ \\
\hline PB2 (g/kg CP) & & $105 \cdot 4$ & & $595 \cdot 3$ \\
\hline PB3 (g/kg CP) & & 101.9 & & $157 \cdot 9$ \\
\hline $\mathrm{PC}(\mathrm{g} / \mathrm{kg} \mathrm{CP})$ & & 31.4 & & $38 \cdot 3$ \\
\hline$P A(g / k g ~ D M)$ & & $43 \cdot 4$ & & $21 \cdot 2$ \\
\hline PB1 (g/kg DM) & & $255 \cdot 1$ & & $64 \cdot 1$ \\
\hline PB2 (g/kg DM) & & $41 \cdot 3$ & & 243.4 \\
\hline PB3 (g/kg DM) & & 39.9 & & 64.5 \\
\hline $\mathrm{PC}(\mathrm{g} / \mathrm{kg} \mathrm{DM})$ & & $12 \cdot 3$ & & $15 \cdot 7$ \\
\hline \multicolumn{5}{|c|}{ Predicted energy value (MJ/kg DM) (NRC, 2001 dairy model and NRC, 1996 beef model) } \\
\hline \multirow[t]{2}{*}{$\operatorname{TDN}_{1 \times}(\%)$} & & $128 \cdot 11$ & & $128 \cdot 14$ \\
\hline & Mcal/kg DM & $\mathrm{MJ} / \mathrm{kg} \mathrm{DM}$ & Mcal/kg DM & $\mathrm{MJ} / \mathrm{kg} \mathrm{DM}$ \\
\hline $\mathrm{DE}_{3 \times}(\mathrm{NRC}, 2001)$ & $5 \cdot 41$ & $22 \cdot 6$ & 5.43 & $22 \cdot 7$ \\
\hline $\mathrm{ME}_{3 \mathrm{X}}(\mathrm{NRC}, 2001)$ & $5 \cdot 20$ & $21 \cdot 8$ & $5 \cdot 24$ & $21 \cdot 9$ \\
\hline $\mathrm{NE}_{\mathrm{L3X}}(\mathrm{NRC}, 2001)$ & 3.75 & $15 \cdot 7$ & 3.80 & $15 \cdot 9$ \\
\hline $\begin{array}{l}\text { Metabolisable energy } \\
\text { (NRC, 1996) }\end{array}$ & 4.83 & $20 \cdot 2$ & 4.85 & $20 \cdot 3$ \\
\hline $\begin{array}{l}\text { Net energy for maintenance } \\
\text { (NRC, 1996) }\end{array}$ & 3.46 & 14.5 & 3.48 & $14 \cdot 6$ \\
\hline $\begin{array}{l}\text { Net energy for growth } \\
\text { (NRC, 1996) }\end{array}$ & 2.53 & $10 \cdot 6$ & 2.54 & $10 \cdot 6$ \\
\hline
\end{tabular}

CP, crude protein; NRC, National Research Council, $T_{D N}$, total digestible nutrient at one times maintenance (NRC, 2001); $D E_{3 x}$ digestible energy at production level of intake (3X; NRC, 2001); $\mathrm{ME}_{3 \mathrm{x}}$, metabolisable energy at production level of intake (3X; NRC, 2001); $\mathrm{NE}_{\mathrm{L3X}}$, net energy for lactation at production level of intake (3X; NRC, 2001).

* See p. 657 for an explanation of the subfractions.

raw flaxseed, which indicated that the roasting increased the undegradable and undigestible protein fractions, which may be an indication of overprocessing and a reduction of protein nutritional value.

\section{Tissue imaging of protein, and protein to starch ratio}

Each biological component has a unique molecular chemical and structural profile, and thus each has its own unique IR spectrum. The characteristic of the protein structure is unique in terms of the peptide bond. The peptide bond contains $\mathrm{C}=\mathrm{O}, \mathrm{C}-\mathrm{N}$ and $\mathrm{N}-\mathrm{H}$ (Fig. 5). The amide $\mathrm{I}$ bond is primarily $\mathrm{C}=\mathrm{O}$ stretching vibration $(80 \%)$ plus $\mathrm{C}-\mathrm{N}$ stretching vibration (Fig. 5). Amide I absorbs at approximately $1650 \mathrm{~cm}^{-1}$. Amide II, which absorbs at $1550 \mathrm{~cm}^{-1}$, consists primarily of $\mathrm{N}-\mathrm{H}$ bending vibrations $(60 \%)$ coupled with $\mathrm{C}-\mathrm{N}$ stretching vibrations (40\%; Fig. 5). Carbohydrates are composed of sugars with $\mathrm{OH}$ and $\mathrm{CO}$ bonds. Depending on the bond linkage and type of sugar, the IR position for carbohydrate lies between 1180 and $950 \mathrm{~cm}^{-1}$. For example, in grain endosperm, starch absorbs at approximately $1025 \mathrm{~cm}^{-1}$ (Himmelsbach et al. 1998; Wetzel et al. 1998, 2003; Jackson \& Mantsch, 2000; Miller, 2000, 2002; Wetzel, 2001; Marinkovic et al. 2002; Yu et al. 2004a).

Fig. 6 represents colour maps of the functional groups of the flaxseed endosperm tissue and single-pixel spectra measuring an area as small as $10 \times 10 \mu \mathrm{m}$ of the sample. These maps show the distribution and relative concentration of the components associated with the flaxseed's inherent microstructure, imaged in terms of a false-colour representation of the chemical intensities. Blue denotes high intensity, red low intensity and white a lack of functional groups. The spectrum in the figure corresponds to the pixel in the cross-hair and was selected to represent the value of the integrated peak. Fig. 6 (A) shows the areas under the $1650 \mathrm{~cm}^{-1}$ peak attributed to protein amide I absorption (Miller, 2000; Wetzel, 2001). Amide I $\left(1650 \mathrm{~cm}^{-1}\right)$ characteristically contains $\mathrm{C}=\mathrm{O}$ and $\mathrm{N}-\mathrm{H}$ bonds in the protein backbone, which indicate the area of the sample where protein is present (Wetzel, 2001; Marinkovic et al. 2002; Miller, 2002). Fig. 6 

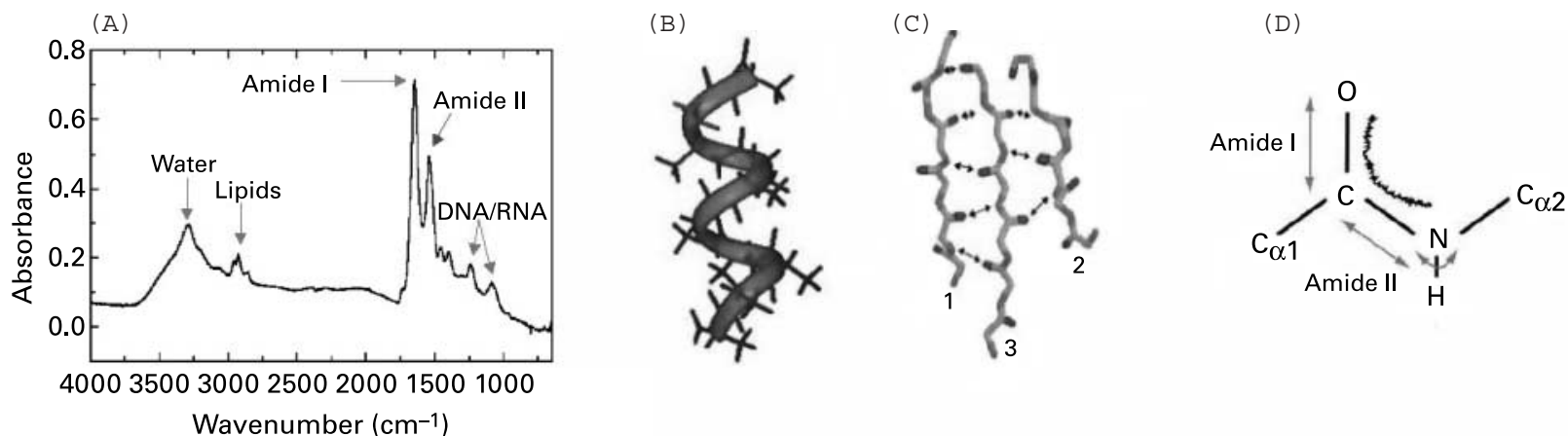

Fig. 5. Protein structure determination with synchrotron-based Fourier transform IR microspectroscopy. The peak positions of amide I are sensitive to the protein secondary structure ( $\alpha$-helix, $\beta$-sheet). (A) Amide I (band $1600-1700 \mathrm{~cm}^{-1}$ ) and amide II (band $1500-1560 \mathrm{~cm}^{-1}$ ). (B) For the $\alpha$-helix, the peak is at approximately $1648-1658 \mathrm{~cm}^{-1}$. (C) For the $\beta$-sheet, the peak lies at approximately $1620-1640 \mathrm{~cm}^{-1}$. (D) Biological system spectra (amide I and II bands in the mid-IR region). (eg Mantsch \& Chapman, 1996; Martin, 2002)

(A)


(B)

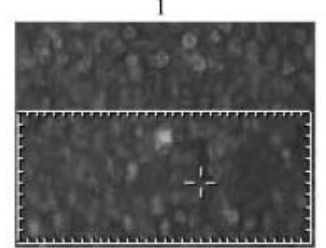

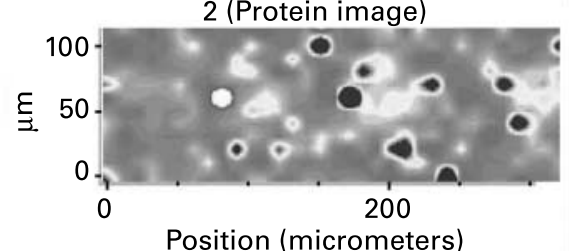

2 (Protein to starch ratio image)
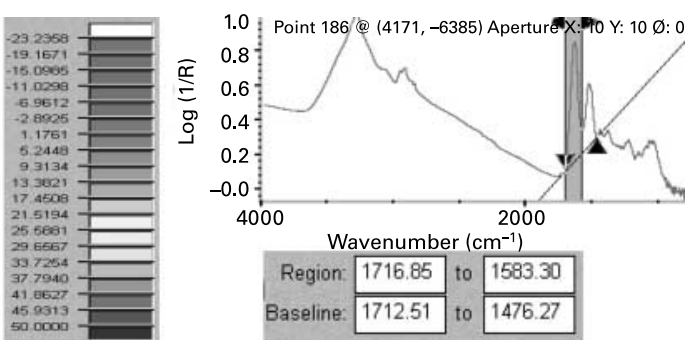

Region: 1716.85 to 1583.30 Baseline: 1712.51 to 1476.27

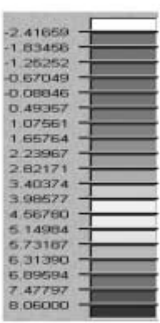

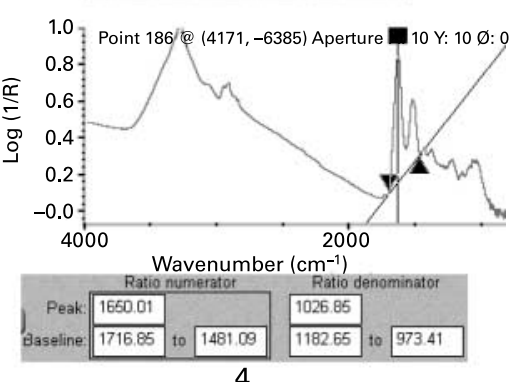

Fig. 6. Protein and protein to starch ratio images of the flaxseed (F1) (a) protein image: area under $1650 \mathrm{~cm}^{-1}$ peak area showing protein amide I intensity and distribution; (b) protein to starch ratio image: area under $1650 \mathrm{~cm}^{-1}$ peak height divided $1025 \mathrm{~cm}^{-1}$ peak height showing protein (amide I) to starch ratio intensity and distribution (1. Visible image; 2 Chemical image; 3. Chemical intensity; 4. Spectra corresponding to the pixel at the cross-hair in the visible image).

(A) clearly shows that protein is unequally distributed in the endosperm areas of the flaxseed tissues, indicating heterogeneity of the flaxseed endosperm.

The biological component ratio images showing the structural chemical features can be obtained by dividing the height or area under one functional group band by the height or area under another functional group band at each pixel. The biological component ratio image has two advantages. The first is that using these ratios eliminates any spectral intensity variations caused by changes in tissue thickness. The second advantage is that the ratio maps are able to indicate the relative biological component contents, which could be used to determine food or feed quality characteristics and nutritive values (nutrient utilisation and availability). Fig. 6 (B) represents peak ratio maps, representing the biological component ratio distribution and intensity in the inherent structure. The height under the $1650 \mathrm{~cm}^{-1}$ band divided by the height under the peaks around $1025 \mathrm{~cm}^{-1}$ at each pixel represent the ratio of protein to total starch in the tissue. Again, Fig. 6 (B) shows that the protein to starch ratio is unequally distributed in the endosperm areas of the flaxseed tissue, indicating endosperm heterogeneity.
The chemical mapping results demonstrate the potential of highly spatially resolved IR microspectroscopy to reveal the flaxseed tissues at a cellular level. The protein and intensity, even within the cellular dimensions of the flaxseed tissues, are unequally distributed, which justifies the need to select areas with relatively 'pure' protein for the study of protein secondary structures, with minimum disturbance from other biological components, such as carbohydrates. Wetzel et al. (2003) and Yu et al. (2004c) also reported a heterogeneous matrix dominated by starch in wheat endosperm and barley endosperm (Yu et al. 2004a).

\section{Characteristics of protein secondary structures of flaxseed tissues}

Typically, protein secondary structures include mainly the $\alpha$-helix and $\beta$-sheet (Fig. 5; Dyson \& Wright, 1990; Carey, 1996). Random coils and $\beta$-turns exist in only small amounts in protein secondary structures. The protein IR spectrum has two primary features, as indicated before - the amide I $\left(1600-1700 \mathrm{~cm}^{-1}\right.$ ) and amide II (approximately $1500-1560 \mathrm{~cm}^{-1}$ ) bands - which arise from specific stretching and bending vibrations of the protein backbone. The amide I band arises predominantly from the $\mathrm{C}=\mathrm{O}$ stretching 
vibration of the amide $\mathrm{C}=\mathrm{O}$ group. The vibrational frequency of the amide I band is particularly sensitive to protein secondary structure (Kemp, 1991; Jackson \& Mantsch, 2000; Miller, 2000, 2002; Martin, 2002; Wetzel et al. 2003) and can be used to predict protein secondary structure. For the $\alpha$-helix, the amide I is typically in the range $1648-1658 \mathrm{~cm}^{-1}$. For the $\beta$-sheet, the peak can be found within the range of $1620-1640 \mathrm{~cm}^{-1}$ (Martin, 2002). Amide II (predominantly an $\mathrm{N}-\mathrm{H}$ bending vibration coupled to $\mathrm{C}-\mathrm{N}$ stretching) is also used to assess protein conformation. As, however, this arises from complex vibrations involving multiple functional groups, the amide II band is less useful for predicting protein structure than the amide I band (Jackson \& Mantsch, 2000). Fig. 2 (A, B) shows the typical protein amide I and amide II spectra of the flaxseed tissues. The spectrum of the original amide I band (baseline 1708$1595 \mathrm{~cm}^{-1}$ ) shows a peak centre at approximately $1650 \mathrm{~cm}^{-1}$, with shoulders at approximately 1690 and 1675 at the left and 1630 and $1600 \mathrm{~cm}^{-1}$ at the right (Fig. 2 (C)). This was confirmed from the FSD spectrum of amide I in the flaxseed tissues (Fig. 2 (D)).

\section{Modelling of protein amide I peaks to quantify the percentage of protein secondary structures}

Owing to the fact that protein amide I component peaks overlap each other (Fig. 2), FSD was used to obtain FSD spectra to identify the amide I component peak frequencies (Fig. 4), which were approximately $1690,1675,1655,1632$ and $1600 \mathrm{~cm}^{-1}$; multicomponent peaks fitting with Gaussian and Lorentzian functions (Fig. 3) were then used to quantify the multicomponent peak area in the protein amide I region. Statistical analysis shows that effect of the flaxseed treatments $(\mathrm{F} 1, \mathrm{~F} 2)$ on all measured parameters was significantly different $(P<0 \cdot 05)$, but fitting methods (Gaussian $v$. Lorentzian) and fitting methods and treatment interactive effects were no different $(P>0.05)$ in the present study.

Table 2 shows the percentage of $\alpha$-helixes and $\beta$-sheets in the protein secondary structures of the flaxseed tissues for raw and roasted golden flaxseeds. Comparing the raw and roasted golden flaxseeds, the roasting reduced $(P<0.05)$ the percentage of $\alpha$ helixes (from $47.1 \%$ to $36.1 \%$; S-FTIR absorption intensity) and increased the percentage of $\beta$-sheets (from $37.2 \%$ to $49.8 \%$; S-FTIR absorption intensity), indicating that roasting may have negatively affected protein quality, utilisation and availability because roasting increased the level of $\beta$-sheets in the roasted flaxseeds. The increase in the number of $\beta$-sheet structures detected after heat treatment may be due to the fact that proteins tend to aggregate after heating at high temperatures, forming intermolecular $\beta$-sheet structures.

Table 3 shows the ratios of $\alpha$-helixes and $\beta$-sheets in the protein secondary structures of the flaxseed tissues in the raw and roasted flaxseeds. Comparing the raw and roasted golden flaxseeds, the roasting reduced $(P<0.05)$ the ratio of $\alpha$-helixes to $\beta$-sheets (from 1.3 to 0.7 ) and increased the $\beta$-sheet to $\alpha$-helix ratio. No published results have been found for the characteristics of the protein secondary structures of flaxseeds, or for the effects of heat treatment or feed-processing. The results indicated that heat-processing might have a significant impact on flaxseed protein secondary structures. In terms of nutritional value, the difference in the percentages of protein secondary structures may be part of the reason underlying the different protein digestive behaviours and availabilities. Information from the present study by the IR probing of protein secondary structures may be valuable as a guide for flaxseed breeders and the feed/food-processing industry to improve and maintain protein nutritional value and quality for animal and human use. The present results demonstrate the potential of highly spatially resolved synchrotronbased IR microspectroscopy to identify 'pure' protein areas in feed tissues, localise the chemical microstructure and reveal the protein secondary structure of flaxseeds at a cellular level, which provide an indication of protein quality.

Protein secondary structures in relation to protein fractions and rumen degradation characteristics of protein fractions

A high proportion of $\beta$-sheet structure may partly cause a low access to gastrointestinal digestive enzymes, which results in a low protein value. Recent research has shown that different feed protein sources have different percentages and ratios of $\alpha$-helixes and $\beta$-sheets in their protein secondary structures (Yu et al. 2004c). These protein structures are highly related to protein values. Feather contains a high protein content ( $84 \%$ ), but its protein digestibility is very low $(5 \%)$ in comparison with that of other protein sources such as barley, oats and wheat. The low digestibility of feather protein is closely related to structural characteristics such as the relationship of $\beta$ sheets to solubility, the keratin content and the disulphide bonding of the amino acids (Ward \& Lundgren 1954; Fraser et al. 1972; Greg \& Rogers, 1986; Chandler, 2003). Our work (Yu et al. 2004c) has shown that feather contains a high ( $88 \%$ ) proportion of $\beta$-sheets and a low (4\%) proportion of $\alpha$-helixes, but the other protein sources with a high protein nutritive value contain a much lower percentage of $\beta$ sheets and a higher one of $\alpha$-helixes: barley, for example, contains $17 \% \beta$-sheets and $71 \% \alpha$-helixes (Yu et al. 2004c).

The present study demonstrated that the differences in the percentages of protein secondary structures, and the $\alpha$-helix to $\beta$-sheet ratio of IR absorption intensity, were partially explained by the different protein digestive behaviours, nutrient utilisation and availability in animals. In the present study, roasting significantly reduced the percentage of $\alpha$-helixes and increased that of

Table 2. Percentage of $\alpha$-helixes and $\beta$-sheets (synchrotron-based Fourier transform IR absorption intensity) in the protein secondary structures of flaxseed tissues at a cellular level: comparison between raw and roasted golden flaxseeds

\begin{tabular}{|c|c|c|c|c|c|c|}
\hline \multirow[b]{2}{*}{ Items } & \multirow[b]{2}{*}{ Sample number } & \multicolumn{2}{|c|}{$\begin{array}{c}\text { Raw flaxseed } \\
(\mathrm{F} 1)\end{array}$} & \multicolumn{2}{|c|}{$\begin{array}{l}\text { Roasted flax- } \\
\text { seed (F2) }\end{array}$} & \multirow[b]{2}{*}{ SEM } \\
\hline & & Value & SD & Value & SD & \\
\hline$\%$ of $\alpha$-helixes & 20 & $47 \cdot 08^{a}$ & $3 \cdot 20$ & $36 \cdot 09^{b}$ & $2 \cdot 89$ & $1 \cdot 315$ \\
\hline$\%$ of $\beta$-sheets & 20 & $37 \cdot 18^{\mathrm{b}}$ & $3 \cdot 35$ & $49 \cdot 75^{a}$ & 3.99 & 1.168 \\
\hline
\end{tabular}

${ }^{a, b}$ Means values within a column with the same letter in the same column are not significantly different $(P>0.05)$. 
Table 3. Ratios of $\alpha$-helixes and $\beta$-sheet (synchrotron-based Fourier transform IR absorption intensity) in the protein secondary structures of flaxseeds: comparison between raw and roasted golden flaxseeds

\begin{tabular}{|c|c|c|c|c|c|c|}
\hline \multirow[b]{2}{*}{ Items } & \multirow[b]{2}{*}{ Sample number } & \multicolumn{2}{|c|}{$\begin{array}{l}\text { Raw flaxseed } \\
\quad(\mathrm{F} 1)\end{array}$} & \multicolumn{2}{|c|}{$\begin{array}{l}\text { Roasted flax- } \\
\text { seed (F2) }\end{array}$} & \multirow[b]{2}{*}{ SEM } \\
\hline & & Value & SD & Value & SD & \\
\hline Ratio of $\alpha$-helix to $\beta$-sheet & 20 & $1 \cdot 28^{\mathrm{a}}$ & 0.20 & $0.73^{b}$ & $0 \cdot 11$ & 0.051 \\
\hline Ratio of $\beta$-sheet to $\alpha$-helix & 20 & $0 \cdot 80^{\mathrm{b}}$ & 0.13 & $1 \cdot 39^{\mathrm{a}}$ & 0.21 & 0.088 \\
\hline
\end{tabular}

${ }^{a, b}$ Means with the same letter in the same column are not significantly different $(P>0.05)$.

$\beta$-sheets, thus increasing the $\beta$-sheet to $\alpha$-helix ratio, which indicated a potential increase in the undegradable and undigestible protein fraction in animals. Using the CNCPS system, it was evident that protein fraction $\mathrm{PC}$, which is undegradable, undigestible and associated with lignin and heat-damaged protein, was also increased. These results suggest that the synchrotron-based IR probing of protein secondary structures might be valuable as a guide for screening the protein quality of feed-processing and treatment in order to prevent overcooking and undercooking. SFTIR microspectroscopy is a non-invasive, non-destructive, rapid-analysis technique capable of revealing feed structure and feed molecular chemistry at a cellular level, unlike traditional 'wet' chemical analyses, which rely heavily on the use of harsh chemicals and derivatisation, therefore altering the native feed structures and possibly generating artefacts. 'Wet' analyses also require reasonable amounts of feed material (gram or milligram levels), which usually means that they are carried out on composite samples of tissues (Stewart et al. 1995). In addition, traditional 'wet' chemical analysis is time-consuming, expensive and prone to errors within and between laboratories.

\section{Conclusion}

In conclusion, S-FTIR microspectroscopy allows the ultrastructural and chemical make-up and nutritive characteristics to be revealed at a high ultraspatial resolution. S-FTIR microspectroscopy was able to identify relatively 'pure' protein in feed tissues and revealed that the secondary structure of protein differed between the raw and roasted golden flaxseeds in terms of the percentages and ratio of $\alpha$-helixes and $\beta$-sheets in the mid-IR range at a cellular level. By using multicomponent peak modelling, the results show that roasting reduced $(P<0 \cdot 05)$ the percentage of $\alpha$ helixes (from $47.1 \%$ to $36.1 \%$; S-FTIR absorption intensity), increased the percentage of $\beta$-sheets (from $37.2 \%$ to $49.8 \%$; SFTIR absorption intensity) and reduced the $\alpha$-helix to $\beta$-sheet ratio (from 1.3 to 0.7 ) in the golden flaxseeds. The present results indicate a negative effect of roasting on protein values, utilisation and availability. The CNCPS system also revealed that roasting increased the amount of protein bound to lignin, and/or Maillard reaction protein (both of which are poorly used by ruminants), and increased the amount of indigestible and undegradable protein. The results demonstrate the potential of highly spatially resolved synchrotron-based IR microspectroscopy to reveal feed protein secondary structures and protein nutritive values. Further study is needed to determine the sensitivity of the protein secondary structures of each feed to various heat-processing methods, and to quantify the relationship between protein secondary structures and the nutrient availability and digestive behaviour of various feed protein sources.

\section{Acknowledgements}

The present study was supported by grants from Natural Sciences and Engineering Research Council of Canada (NSERC Discovery Grant-Individual) and Saskatchewan Agricultural Development Fund. The National Synchrotron Light Source in Brookhaven National Laboratory (New York, USA) is supported by the US Department of Energy contract DE-AC02-98CH10886. We are grateful to L. M. Miller and N. S. Marinkovic (NSLS-BNL, New York, USA) for helpful data collection at U2B and U10B synchrotron stations, to D. A. Christensen, J. J. McKinnon (University of Saskatchewan) and C. R. Christensen (CLS) for research support, and to $\mathrm{H}$. Soita for laboratory chemical analysis.

\section{References}

Association of Official Analytical Chemists (1990) Official Methods of Analysis, 15th edn. Arlington, VA: AOAC.

Budevska BO (2002) In Handbook of Vibrational Spectroscopy, vol. 5. Applications of Vibrational Spectroscopy in Life, Pharmaceutical and Natural Sciences, pp. 3720-3732. (JM Chalmers and PR Griffiths, editors). New York: John Wiley and Sons, Inc.

Carey FA (1996) Organic Chemistry, 3rd edn. New York: McGraw-Hill.

Chalupa W \& Sniffen CJ (1994) Carbohydrate, protein and amino acid nutrition of lactating dairy cattle. In Recent Advances in Animal Nutrition, pp. 265-275 (Garnsworty PC \& Wiseman J, editors) Loughborough: Nottingham University Press.

Chandler NJ (2003) Dairy Cattle - Feather meal: its nutritional value and use in dairy and beef rations. http://www.engormix.com/e_articles_dairy_cattle. asp?ID=79 (November 2003)/

Chaudhry AS \& Webster AJF (1993) The true digestibility and biological value for rats of undegraded dietary nitrogen in feeds for ruminant. Anim Feed Sci Technol 42, 209-221.

Dumas P (2003) Synchrotron IR microspectroscopy: a multidisciplinary analytical technique. Sixth Annual Synchrotron CLS Users' Meeting and Associated Synchrotron Workshops - WinXAS and Infrared. University of Saskatchewan, Canada, 13-15 November.

Dyson HJ \& Wright PE (1990) Peptide conformation and protein folding. Curr Opin Struct Biol 3, 60-65.

Elizalde JC, Merchen NR \& Faulkner DB (1999) Fractionation of fiber and crude protein in fresh forages during the spring growth. $J$ Anim Sci 77, 476-484.

Fraser RDB, MacCrae TP \& Rogers GE (1972) Keratins. Springheld, USA: Charles C Thomas.

Goelema JO (1999) Processing of legume seeds: effect on digestive behaviours in dairy cows. $\mathrm{PhD}$ Thesis, Wageningen Agricultural University, The Netherlands.

Greg K \& Rogers GE (1986) Feather keratin: composition, structure and biogenesis. In Biology of Integuments, vol. 2. Heidelberg: Springer Verlag.

Griffiths PR \& Pariente G (1986) Trends in analytical chemistry. In Introduction to Spectral Deconvolution, vol. 5, p. 209. Amsterdam, Netherlands: Elsevier. 
Himmelsbach DS, Khalili S \& Akin DE (1998) FT-IR microspectroscopic imaging of flax (Linum usitatissimum L.) stems. Cell Mol Biol 44, 99-108.

Holman Hoi-Ying N, Bjornstad KA, McNamara MP, Martin MC, McKinney WR \& Blakely EA (2002) Synchrotron infrared spectromicroscopy as a novel bioanalytical microprobe for individual living cells: cytotoxicity considerations. J Biomed Optics 7, 1-10.

Holum JR (1982) Fundamentals of General, Organic, and Biological Chemistry, 2nd edn. New York: J Wiley \& Sons.

Jackson M \& Mantsch HH (2000) Infrared spectroscopy ex vivo tissue analysis. In Encyclopedia of Analytical Chemistry, pp. 1-20 (Meyers L, ed.). Chichester: John Wiley and Sons Ltd.

Kauppinen JK, Moffatt DJ, Mantsch HH \& Cameron DG (1981) Fourier selfdeconvolution: a method for resolving intrinsically overlapped bands. Appl Spectroscy 35, 271-276.

Kemp W (1991) Organic Spectroscopy, 3rd edn., New York: WH Freeman.

Licitra G, Hernandez TM \& Van Soest PJ (1996) Standardization of procedures for nitrogen fractionation of ruminant feeds. Anim Feed Sci Technol 57, 347-358.

Mantsch HH \& Chapman D (1996) Infrared Spectroscopy of Biomolecules. New York: John Wiley \& Sons.

Marinkovic NS, Huang R, Bromberg P, et al. (2002) Center for Synchrotron Biosciences' U2B beamline: an international resource for biological infrared spectroscopy. J Synchrotron Radiat 9, 189-197.

Martin MC (2002) Fourier-transform infrared spectroscopy. http://www nsls.bnc-gov/newsroom/publications/otherpubs/imaging0502/ workshopmillerhighres.pdf (accessed 7 Sep 2005)

Miller LM (2000) The impact of infrared synchrotron radiation on biology: past, present, and future. Synchrotron RadiatNews 13, 31-37.

Miller LM (2002) Infrared microspectroscopy and imaging. http://www.nsls.bnlgov/newsroom/publications/otherpubs/imaging0502/workshopmillerhighres. $\operatorname{pdf}($ accessed7sep05)

National Research Council (1996) Nutrient Requirement of Beef Cattle, 7th edn. Washington, DC: National Academy Press.

National Research Council (2001) Nutrient Requirement of Dairy Cattle, 7th edn. Washington, DC: National Academy Press.

Rebolé A, Treviño J, Caballero R \& Alzueta C (2001) Effect of maturity on the amino acid profiles of total and nitrogen fractions in common vetch forage. J Sci Food Agric 81, 455-461.

SAS (1998) User's Guide: Statistics, 8th edn., Cary, NC: SAS Institute.

Seguchi M, Takemoto M, Mizutani U, Ozawa M, Nakamura C \& Matsumura Y (2004) Effects of secondary structures of heated egg white protein on the binding between prime starch and tailings fractions in fresh wheat flour. Cereal Chem 81, 633-636.

Sniffen CJ, O'Connor JD, Van Soest PJ, Fox DG \& Russell JB (1992) A net carbohydrate and protein system for evaluating cattle diets II. Carbohydrate and protein availability. J Anim Sci 70, 3562-3577.

Soita HW, Meier JA, Fehr M, Yu P, Christensen DA, McKinnon JJ \& Mustafa AF (2003) Effects of flaxseed supplementation on milk production, milk fatty acid composition and nutrient utilization by lactating dairy cows. Arch Anim Nutr 57, 107-116.

Stewart D, McDougall GJ \& Baty A (1995) Fourier transform infrared microspectroscopy of anatomically different cells of falx (Linum usitatissimum) stems during development. J Agric Food Chem 43, $1853-1858$.

Van der Poel AFB, Blonk J, van Zuilichem DJ \& van Oort MG (1990) Thermal inactivation of lectins and trypsin inhibitor activity during steam processing of dry beans (Phaseolus vulgaris) and effects on protein quality. J Sci Food Agric 53, 215-228.

Van Soest PJ, Robertson JB \& Lewis BA (1991) Symposium: Carbohydrate methodology, metabolism and nutritional implications in dairy cattle. Methods for dietary fiber, neutral detergent fiber and non-starch polysaccharides in relation to animal nutrition. J Dairy Sci 74, 3583-3597

Ward \& Lundgren HP (1954) Formation, composition and properties of keratins. Adv Protein Chem 9, 244-297.
Weiss WP, Conrad HR \& Pierre NS (1992) A theoretically based model for predicting total digestible nutrient values of forages and concentrates. Anim Feed Sci Technol 39, 95-110.

Wetzel DL (2001) When molecular causes of wheat quality are known, molecular methods will supercede traditional methods. Proceedings of the Second International Wheat Quality Conference, Manhattan, Kansas, USA, May. 2001.

Wetzel DL, Eilert AJ, Pietrzak LN, Miller SS \& Sweat JA (1998) Ultraspatially resolved synchrotron infrared microspectroscopy of plant tissue in situ. Cell Mol Biol 44, 145-167.

Wetzel DL, Srivarin P \& Finney JR (2003) Revealing protein infrared spectral detail in a heterogeneous matrix dominated by starch. Vib Spectrosc 31, 109-114.

Yu P (2004) Application of advanced synchrotron-based Fourier transform infrared microspectroscopy (SR-FTIR) to animal nutrition and feed science: a novel approach. Br J Nutr 92, 869-885.

Yu P, Goelema JO, Leury BJ, Tamminga S \& Egan AR (2002) An analysis of the nutritive value of heat processed legume seeds for animal production using the DVE/OEB model: a review [Scientific review article]. Anim Feed Sci Technol 99, 141-176.

Yu P, McKinnon JJ, Christensen CR, \& Christensen DA (2003a) Mapping plant composition with synchrotron infrared microspectroscopy and relation to animal nutrient utilization [Invited article and conference speech]. Proceedings of the Canadian Society of Animal Science Conference, University of Saskatchewan, Saskatoon, Canada, 10-13 June.

Yu P, McKinnon JJ, Christensen CR, Christensen DA, Marinkovic NS \& Miller LM (2003b) Chemical imaging of micro-structures of plant tissues within cellular dimension using synchrotron infrared microspectroscopy. J Agric Food Chem 51, 6062-6067.

Yu P, McKinnon JJ, Christensen CR \& Christensen DA (2004a) Using synchrotron-based FTIR microspectroscopy to reveal chemical features of feather protein secondary structure: comparison with other feed protein sources. J Agric Food Chem 52, 7353-7361.

Yu P, Tamminga S, Egan AR \& Christensen DA (2004b) Probing equivocal effects of heat processing of legume seeds on performance of ruminants - a review [Scientific review article]. Asian Austr J Anim Sci 17, 869-876.

Yu P, Christensen DA, Christensen CR, Drew MD, Rossnagel BG \& McKinnon JJ (2004c) Use of synchrotron FTIR microspectroscopy to identify chemical differences in barley endosperm tissue in relation to rumen degradation characteristics. Can J Anim Sci 84, 523-527.

Yu P, McKinnon JJ, Christensen DA \& Christensen CR (2004d) Applications of synchrotron technology (SR-FTIR) to feed analysis and utilization: a novel approach [Conference article]. Proceedings of the 25th Western Nutrition Conference, Nutrient Requirement and Ingredient Evaluation in the 21st Century. Saskatoon, Canada, 28-30 September.

Yu P, McKinnon JJ, Christensen CR \& Christensen DA (2004e) Using synchrotron transmission FTIR microspectroscopy as a rapid, direct and non-destructive analytical technique to reveal molecular microstructural-chemical features within tissue in grain barley. J Agric Food Chem 52, 1484-1494.

Yu P, McKinnon JJ, Christensen CR \& Christensen DA (2004f) Imaging molecular chemistry of Pioneer corn. J Agric Food Chem $\mathbf{5 2}$ 7345-7352.

Yu P, Christensen DA, McKinnon JJ \& Soita HW (2004g) Using chemical and biological approaches to predict energy values of selected forages affected by variety and maturity stage. Asian Austr J Anim Sci 17, $228-236$.

Yu P (2005a) Using synchrotron infrared microspectroscopy to reveal microstructural-chemical features of feed/food/plant tissues at a cellular and subcellular level [Invited conference article and speech]. 96th American Oil Chemists Society Annual Conference and Expo, Salt Lake City, Utah, USA, 1-4 May.

Yu P (2005b) Application of cluster analysis (CLA) in feed chemical imaging to accurately reveal structural-chemical features of feeds within cellular dimension. J Agric Food Chem 53, 2872-2880. 